\title{
STOCHASTIC FRONTIER ANALYSIS (SFA): PENGUKURAN EFISIENSI DIREKTORAT JENDERAL PAJAK (DJP) DALAM PENGELOLAAN DANA PAJAK
}

\author{
Ratna Herawati ${ }^{1)}$ \\ Fakultas Ekonomi dan Bisnis Universitas Dian Nuswantoro \\ J1. Imam Bonjol No.207, Pendrikan Kidul, Kec. Semarang Tengah, Kota Semarang \\ E-mail: rathna.hiera@dsn.dinus.ac.id \\ Risanda A. Budiantoro ${ }^{2)}$ \\ Fakultas Ekonomi dan Bisnis Universitas Dian Nuswantoro \\ Jl. Imam Bonjol No.207, Pendrikan Kidul, Kec. Semarang Tengah, Kota Semarang \\ Amalia Nur Chasanah ${ }^{3)}$ \\ Fakultas Ekonomi dan Bisnis Universitas Dian Nuswantoro \\ Jl. Imam Bonjol No.207, Pendrikan Kidul, Kec. Semarang Tengah, Kota Semarang
}

\begin{abstract}
This study aims to measure technical efficiency and identify factors that affect efficiency of Direktorat Jenderal Pajak (DJP) (consists of 33 DJP's Regional Offices and one DJP's Head Office) in managing tax funds on receipt. Data that we use are time unbalanced panel data from 2012 until 2019. The input variables used are total assets and operational costs, while the output variables are the receipt of pajak funds. Using stochastic frontier analysis, this study has successfully identified that total assets and operational costs had a a positive and significant effect on receipt of pajak funds. Overall, technical efficiency in receipt of pajak funds of DJP are found to be 86,63 percent, which means there are about 13,36 percent that can still be optimized.
\end{abstract}

Keywords : Direktorat Jenderal Pajak (DJP), Stochastic Frontier Analysis, Technical Efficienc

PENDAHULUAN

Latar Belakang

Di Indonesia, pajak merupakan sumber pendapatan negara yang paling besar, dengan target di tahun 2018 sebesar 1.618,1 triliun (Kemenkeu, 2018), dengan proporsi yang cukup besar ini muncul realitas bahwa pemerintah masih menjadikan pajak sebagai pendapatan utama negara dan sebagai instrumen fiskal dalam mengambil langkah perbaikan ekonomi dengan cara membuat peraturan yang tepat, melakukan pemungutan pajak secara benar dan melakukan pengawasan, meskipun tidak dapat dipungkiri bahwa peran dari sektor pendapatan lainnya juga sangat diperlukan (Kader et al. 2015).
Direktorat Jenderal Pajak (DJP) merupakan salah satu unit kerja Pemerintah pusat dengan level eselon I terbesar di Indonesia, sebagai organisasi yang berperan sebagai pusat penerimaan terbesar, DJP bertanggung jawab terhadap terkumpulnya lebih dari $85,4 \%$ penerimaan negara, berupa pajak (APBN, 2018). Selama ini, kinerja DJP dan unitunit vertikalnya seringkali hanya diukur berdasarkan ukuran pencapaian realisasi penerimaan pajak maupun pertumbuhannya, ukuran capaian penerimaan pajak tersebut cenderung bias (Setiyaji dan Amir 2005).

Pada tahun 2017, pasca diterbitkannya Undang-Undang Keterbukaan Informasi Keuangan, tuntutan akan peningkatan 
penerimaan pajak, peningkatan kesadaran dan kepatuhan wajib pajak serta diperlukannya perbaikan-perbaikan dan perubahan dalam segala aspek perpajakan menjadi alasan utama dilakukan reformasi perpajakan. Reformasi perpajakan tersebut berupa penyempurnaan terhadap kebijakan perpajakan dan sistem administrasi perpajakan sehingga dalam penerapannya diharapkan dapat meningkatkan kepatuhan wajib pajak. Konsep modernisasi adminitrasi perpajakan pada prinsipnya merupakan suatu pola sistem adminitrasi yang dapat mengubah pola pikir dan perilaku aparat serta tata nilai nilai yang dianut organisasi sehingga diharapkan dapat menjadikan Direktorat Jenderal Pajak (DJP) menjadi institusi yang profesional dan memiliki citra baik di masyarakat. Sehingga, dibutuhkan ukuran kinerja alternatif yang mampu memenuhi unsur daya banding (comparability), yang tetap relevan digunakan dalam menilai kinerja administrasi perpajakan, salah satu ukuran kinerja tersebut adalah ukuran kinerja efisiensi (OECD, 2013, 2015).

Sadjiarto (2000) mengungkapkan, informasi kinerja efisiensi sangat dibutuhkan baik oleh internal Pemerintah maupun stakeholdernya, masyarakat sebagai stakeholder dan pengguna layanan dan barang publik, untuk menilai akuntabilitas dan pertanggungjawaban pemerintah atas penggunaan sumber daya, seperti sumber daya alam, pajak, tenaga kerja dan sebagainya, dalam menyediakan layanan dan barang publik, termasuk DJP. Pemerintah menggunakan informasi efisiensi dalam rangka pengambilan keputusan, seperti alokasi sumber daya, keputusan untuk melanjutkan, atau menghentikan suatu program atau kegiatan (Mahsun, 2014) atau keputusan pemberian reward dan punishment (Mardiasmo, 2009). Mengingat pentingnya menilai kinerja sebuah organisasi dalam hal ini
DJP, Maka dari itu dibutuhkan sebuah analisis efisiensi, untuk menentukan strategi yang tepat guna untuk meningkatkan kinerja DJP dalam menjalankan perannya sebagai organisasi pengelola pajak.

\section{LANDASAN TEORI}

\section{Pajak}

Pajak adalah kontribusi wajib kepada negara yang terutang oleh orang pribadi atau badan yang bersifat memaksa berdasarkan undang-undang, dengan tidak mendapat imbalan secara langsung dan digunakan untuk keperluan negara bagi sebesar-besarnya kemakmuran rakyat (UU No.6 Tahun 1983 tentang KUP sebagaimana telah diubah dengan UU No. 16 Tahun 2009). Menurut Ahmadi (2006), menyatakan bahwa pajak adalah suatu sumbangan paksaan dari peorangan kepada pemerintah untuk membiayai pengeluaran yang berkaitan dengan kepentingan orang banyak (umum) tanpa ditunjukan keuntungan khusus.

\section{Direktorat Jenderal Pajak (DJP)}

Direktorat Jenderal Pajak menetapkan empat tujuan strategis dalam rangka mewujudkan visi dan misi DJP, yaitu: (a) Peningkatan pelayanan perpajakan; (b) Peningkatan kepatuhan Wajib Pajak melalui pengawasan dan penegakan hukum; (c) Peningkatan efektivitas dan efisiensi organisasi melalui reformasi dan modernisasi; (d) Peningkatan profesionalisme dan integritas sumber daya manusia. Keempat tujuan strategis tersebut mengarah pada pencapaian tujuan eksternal dan internal. Tujuan eksternal mengarahkan perhatian kepada Wajib Pajak meliputi peningkatan pelayanan perpajakan dan peningkatan kepatuhan 
ISSN : $2406-7415$

E-ISSN : $2655-9919$

JURNAL AKUNTANSI DAN BISNIS KRISNADWIPAYANA

DOI: http://dx.doi.org/10.35137/jabk.v8i1.469

Volume 8 Nomor 1 (Januari - April) 2021

Wajib Pajak melalui pengawasan dan penegakan hukum. Sedangkan tujuan internal mengarahkan kepada pengembangan sumber daya internal DJP meliputi peningkatan efektivitas dan efisiensi organisasi melalui reformasi dan modernisasi dan peningkatan profesionalisme dan integritas sumber daya manusia. Pengembangan sumber daya internal meliputi pengembangan organisasi, proses bisnis, teknologi informasi, anggaran, dan SDM.

\section{Teori Efisiensi}

Efisiensi merupakan ukuran efektivitas yang menghasilkan peminimalisiran waktu, tenaga, dan keterampilan yang terbuang (Archer 2010). Dalam hal ini efisiensi selalu berkaitan dengan adanya variabel input dan output sehingga efisiensi diartikan sebagai rasio input dan output. Terdapat tiga faktor yang menyebabkan terjadinya efisiensi, antara lain (Permono dan Darmawan 2000):

1. Apabila dengan input yang sama dapat menghasilkan output yang lebih besar

2. Dengan input yang lebih kecil dapat menghasilkan output yang sama besar

3. Dengan input yang lebih besar dapat mengahasilkan output dengan persentase yang lebih besar

Secara sederhana efisiensi dibagi dua, yaitu (Bauer, et al. 1998):

1. Efisiensi Teknis (konteks mikroekonomi)

Adanya hubungan teknis antara variabel input dan output yang digunakan dalam proses produksi. Dengan menggunakan efisiensi teknis perusahaan diharapkan mampu menghasilkan outut yang maksimal dengan penggunaan input yang tersedia.

2. Efisiensi ekonomis (konteks makroekonomi)

Konsep efisiensi ekonomi memiliki cakupan yang lebih luas dibandingkan dengan konsep efisiensi teknis. Perusahaan harus dapat menentukan tingkatan input dan output yang digunakan untuk mengoptimalkan tujuan ekonomi (minimalisasi biaya atau maksimalisasi keuntungan).

Efisiensi dapat diukur, dinilai dan dianalisis dengan menggunakan suatu pendekatan, baik pendekatan parametrik maupun pendekatan nonparametrik (Hjalmarsson et al. 1996). Dalam penelitian ini, penulis menggunakan metode parametrik yang melibatkan variabel input dan output dengan nilai yang beragam serta bersifat stochastic, yaitu Stochastic Frontier Analysis (SFA) dengan fungsi translog kemudian diestimasi regresi Ordinary Least Square dan menggunakan maximum likelihood estimator.

Beberapa penelitian sebelumnya, terkait perhitungan efisiensi pada sektor perpajakan di berbagai otoritas perpajakan pada berbagai negara, seperti: Thirtle et al. (2000) yang melakukan pengukuran efisiensi otoritas perpajakan di 15 negara bagian India dengan Data Envelopment Analysis (DEA), 1980-1992, hasilnya menunjukkan Rata-rata skor technical efficiency menunjukkan skor 0,99 dengan rata-rata peningkatan tahunannya sebesar 3,96 persen. Moesen dan Persoon (2002) yang melakukan perhitungan efisiensi dari 289 kantor pajak di Belgia dengan Data Envelopment Analysis (DEA) hasilnya menunjukkan besaran skor technical efficiency sebesar 0,88. Barros (2007) yang meneliti efisiensi teknis dan efisiensi alokatif dari 41 unit kantor pajak di Portugal dengan rata-rata skor sebesar 0,891. Triantoro dan Subroto (2016) 
ISSN : $2406-7415$

E-ISSN : $2655-9919$

JURNAL AKUNTANSI DAN BISNIS KRISNADWIPAYANA

DOI: http://dx.doi.org/10.35137/jabk.v8i1.469

Volume 8 Nomor 1 (Januari - April) 2021

melakukan perhitungan efisiensi di 10 KPP di Kantor Wilayah Jawa Timur III, 2012-2014 hasilnya menunjukkan bahwa skor technical efficiency menunjukkan 0,944 .

\section{Hipotesis Penelitian}

Adapun hipotesis penelitian untuk periode pengamatan 2012-2016 adalah:

1. Beban operasional diduga memiliki pengaruh positif terhadap penerimaan dana pajak, 2012-2019

2. Total aset diduga memiliki pengaruh positif terhadap penerimaan dana pajak, 2012-2019

\section{METODE PENELITIAN}

\section{Model Penelitian}

Melihat penelitian sebelumnya yang sudah pernah dilakukan dan dengan melakukan penyesuaian yang dianggap akan memberikan hasil yang diharapkan untuk dapat menjelaskan efisiensi pada DJP dalam pengelolaan dana pajak. Penelitian ini menggunakan metode paramterik SFA dengan pendekatan fungsi produksi. Sehingga, berpengaruh terhadap penentuan variabel input dan output yang digunakan. Hal yang mendasari pendekatan ini dengan mempertimbangkan fungsi dari DJP sebagai instansi yang mengelola dana pajak secara efisien. Bentuk umum dari metode SFA dengan fungsi produksi dituliskan sesuai dengan fungsi produksi Cobb-Douglas, ditunjukkan pada Persamaan 3.1 berikut:

$\ln \left(\mathbf{Q}_{\mathrm{n}}\right)=\propto+\beta_{1} \ln \left(\mathrm{P}_{1}\right)+\beta_{\mathbf{2}} \ln \left(\mathrm{P}_{2}\right)$ $+\epsilon_{\mathrm{t}}$

Dengan memasukan variabel input dan output ke dalam fungsi produksi Cobb-Douglas maka persamaan dapat ditulis kembali pada persamaan 3.2 berikut:

$$
\begin{aligned}
& \ln \left(\mathbf{Q}_{1}\right)=\propto+\beta_{1} \ln \left(\mathbf{P}_{1}\right)+\beta_{2} \ln \left(\mathbf{P}_{2}\right) \\
& +\mathbf{U}_{\mathrm{t}}-\mathrm{V}_{\mathrm{t}} \\
& \text { Keterangan : } \\
& \mathrm{Q}_{1}=\text { Penerimaan dana pajak } \\
& \mathrm{P}_{1}=\text { Beban operasional } \\
& \mathrm{P}_{2}=\text { Total aset } \\
& \mathrm{U}_{\mathrm{t}}=\text { faktor acak yang dapat } \\
& \text { dikendalikan (inefisiensi) } \\
& \mathrm{V}_{\mathrm{t}}=\text { faktor acak yang tidak } \\
& \text { dapat dikendalikan }
\end{aligned}
$$

Dari persamaan 3.2 diatas maka $\mathrm{P}_{1}$ dan $\mathrm{P}_{2}$ menunjukkan variabel input yang digunakan pada DJP pada periode tertentu dalam penelitian ini, sedangkan $Q_{n}$ menunjukkan kuantitas output dalam penelitian ini pada Direktoral Jenderal Pajak pada periode tertentu.

\section{Variabel Output}

Dalam penelitian ini menggunakan satu variabel output, yaitu:

\section{Penerimaan Dana Pajak Neto}

Penerimaan dana pajak neto merupakan total keseluruhan dana pajak yang telah berhasil dihimpun dari para wajib pajak dalam periode tertentu. Penerimaan dana pajak adalah penjumlahan dari Pendapatan PPh Migas, Pendapatan PPh Non-Migas, Pendapatan PPN, Pendapatan PPnBM, Pendapatan Pajak Bumi dan Bangunan, Pendapatan Pajak Lainnya, dan Pendapatan Bunga Penagihan Pajak. Besaran penerimaan pajak dapat diperoleh dari laporan keuangan tahunan yang secara berkala diterbitkan oleh DJP yang bersangkutan selama rentang periode pengamatan.

\section{Variabel Input}

Dalam penelitian ini, terdapat dua variabel input yang digunakan antara lain:

\section{Beban Operasional}

Beban operasional merupakan biaya langsung yang digunakan untuk kebutuhan 
ISSN : $2406-7415$

E-ISSN : $2655-9919$

JURNAL AKUNTANSI DAN BISNIS KRISNADWIPAYANA

DOI: http://dx.doi.org/10.35137/jabk.v8i1.469

Volume 8 Nomor 1 (Januari - April) 2021

operasional perusahaan. Berdasarkan objek studi yang digunakan ini ialah DJP, maka yang menjadi beban operasionalnya semua biaya-biaya yang dikeluarkan untuk keperluan yang menunjang kegiatan manajemen lembaga dalam pengelolaan pajak, antara lain: Belanja Pegawai, Belanja Barang, dan Belanja Modal. Besaran beban operasional dapat diperoleh dari laporan keuangan tahunan pada laporan arus kas yang secara berkala diterbitkan oleh DJP yang bersangkutan selama rentang periode pengamatan.

\section{Total Aset}

Total aset merupakan keseluruhan aset yang dimiliki oleh DJP baik aset lancar, aset tetap dan aset lainnya. Total aset dapat diperoleh dari laporan keuangan tahunan pada laporan posisi keuangan yang secara berkala diterbitkan oleh DJP yang bersangkutan selama rentang periode pengamatan.

\section{Jenis dan Sumber Data}

Objek penelitian yang digunakan dalam penelitian ini merupakan instansi resmi pemerintah yang tugas dan fungsinya melakukan pengelolaan dana pajak, yaitu Direktorat Jenderak Pajak (terdiri atas 33 Kantor Wilayah DJP dan Kantor Pusat DJP) (lihat Tabel 1). Pemiihan objek penelitian ini dengan dasar pertimbangan bahwa 33 Kantor Wilayah DJP ini berperan penting dalam melaksanakan teknis operasional pengelolaan dana pajak di daerah. Sedangkan untuk jenis data yang digunakan adalah data sekunder yang diperoleh dari laporan keuangan DJP yang dipublikasikan secara berkala dalam rentang periode 2012-2019 (data unbalanced panel) dan literatur lainnya yang berkaitan dengan efisiensi pengelola dana pajak nasional.

\section{Tabel 1. DJP yang digunakan sebagai objek penelitian}

\begin{tabular}{|c|c|c|}
\hline Kode & Kanwil DJP & Lokasi \\
\hline 1 & Kanwil DJP Aceh & Banda Aceh \\
\hline \multirow[t]{2}{*}{2} & Kanwil DJP & Medan \\
\hline & Sumatera Utara I & \\
\hline \multirow[t]{2}{*}{3} & Kanwil DJP & Pematang \\
\hline & Sumatera Utara II & Siantar \\
\hline 4 & $\begin{array}{l}\text { Kanwil DJP Riau } \\
\text { dan Kepulauan } \\
\text { Riau }\end{array}$ & Pekanbaru \\
\hline \multirow[t]{2}{*}{5} & Kanwil DJP & Padang \\
\hline & $\begin{array}{l}\text { Sumatera Barat } \\
\text { dan Jambi }\end{array}$ & \\
\hline \multirow[t]{2}{*}{6} & Kanwil DJP & Palembang \\
\hline & $\begin{array}{l}\text { Sumatera Selatan } \\
\text { dan Babel }\end{array}$ & \\
\hline \multirow[t]{3}{*}{7} & Kanwil DJP & Lampung \\
\hline & Bengkulu dan & \\
\hline & Lampung & \\
\hline \multirow[t]{2}{*}{8} & Kanwil DJP & Jakarta \\
\hline & Jakarta Pusat & \\
\hline \multirow[t]{2}{*}{9} & Kanwil DJP & Jakarta \\
\hline & Jakarta Barat & \\
\hline \multirow[t]{2}{*}{10} & Kanwil DJP & Jakarta \\
\hline & Jakarta Selatan & \\
\hline \multirow[t]{2}{*}{11} & Kanwil DJP & Jakarta \\
\hline & Jakarta Timur & \\
\hline \multirow[t]{2}{*}{12} & Kanwil DJP & Jakarta \\
\hline & Jakarta Utara & \\
\hline \multirow[t]{2}{*}{13} & Kanwil DJP & Jakarta \\
\hline & Jakarta Khusus & \\
\hline \multirow[t]{2}{*}{14} & Kanwil DJP & Serang \\
\hline & Banten & \\
\hline \multirow[t]{2}{*}{15} & Kanwil DJP Jawa & Bandung \\
\hline & Barat I & \\
\hline \multirow[t]{2}{*}{16} & Kanwil DJP Jawa & Bekasi \\
\hline & Barat II & \\
\hline \multirow[t]{2}{*}{17} & Kanwil DJP Jawa & Semarang \\
\hline & Tengah I & \\
\hline \multirow[t]{2}{*}{18} & Kanwil DJP Jawa & Surakarata \\
\hline & Tengah II & \\
\hline
\end{tabular}


ISSN : $2406-7415$

E-ISSN : $2655-9919$

JURNAL AKUNTANSI DAN BISNIS KRISNADWIPAYANA

DOI: http://dx.doi.org/10.35137/jabk.v8i1.469

Volume 8 Nomor 1 (Januari - April) 2021

\begin{tabular}{|c|c|c|}
\hline 19 & $\begin{array}{l}\text { Kanwil DJP D.I. } \\
\text { Yogyakarta }\end{array}$ & Yogyakarta \\
\hline 20 & $\begin{array}{l}\text { Kanwil DJP Jawa } \\
\text { Timur I }\end{array}$ & Surabaya \\
\hline 21 & $\begin{array}{l}\text { Kanwil DJP Jawa } \\
\text { Timur II }\end{array}$ & Sidoarjo \\
\hline 22 & $\begin{array}{l}\text { Kanwil DJP Jawa } \\
\text { Timur III }\end{array}$ & Malang \\
\hline 23 & $\begin{array}{l}\text { Kanwil DJP } \\
\text { Kalimantan Barat }\end{array}$ & Pontianak \\
\hline 24 & $\begin{array}{l}\text { Kanwil DJP } \\
\text { Kalimantan } \\
\text { Selatan dan } \\
\text { Tengah }\end{array}$ & Banjarmasin \\
\hline 25 & $\begin{array}{l}\text { Kanwil DJP } \\
\text { Kalimantan Timur }\end{array}$ & Balikpapan \\
\hline 26 & $\begin{array}{l}\text { Kanwil DJP } \\
\text { Sulawesi Selatan, } \\
\text { Barat dan } \\
\text { Tenggara }\end{array}$ & Makassar \\
\hline 27 & $\begin{array}{l}\text { Kanwil DJP } \\
\text { Sulawesi Utara, } \\
\text { Tengah dan } \\
\text { Maluku Utara }\end{array}$ & Manado \\
\hline 28 & Kanwil DJP Bali & Denpasar \\
\hline 29 & $\begin{array}{l}\text { Kanwil DJP Nusa } \\
\text { Tenggara }\end{array}$ & Mataram \\
\hline 30 & $\begin{array}{l}\text { Kanwil DJP Papua } \\
\text { dan Maluku }\end{array}$ & Jayapura \\
\hline 31 & $\begin{array}{l}\text { Kanwil DJP Wajib } \\
\text { Pajak Besar }\end{array}$ & Jakarta \\
\hline 32 & $\begin{array}{l}\text { Kanwil DJP } \\
\text { Jakarta Selatan II }\end{array}$ & Jakarta \\
\hline 33 & $\begin{array}{l}\text { Kanwil DJP Jawa } \\
\text { Barat III }\end{array}$ & Bogor \\
\hline 34 & $\begin{array}{l}\text { Instansi Pusat } \\
\text { er: DIP (2019) }\end{array}$ & Jakarta \\
\hline
\end{tabular}

menentukan nilai efisiensi dalam penerimaan dana pajak.

\section{Uji Kriteria Statistik \\ Uji Signifikansi Parameter Individual (Uji Statistik T)}

Pengujian signifikansi untuk mengetahui pengaruh setiap variabel bebas terhadap variabel terikat yang digunakan, sebagai berikut:

1. Apabila $\mathrm{t}$ hitung lebih besar daripada $\mathrm{t}$ tabel, maka $\mathrm{H}_{0}$ ditolak dan $\mathrm{H}_{1}$ diterima. Artinya variabel bebas secara individual berpengaruh signifikan terhadap variabel terikat.

2. Apabila $t$ hitung lebih kecil daripada $t$ tabel, maka $\mathrm{H}_{0}$ diterima dan $\mathrm{H}_{1}$ ditolak. Artinya variabel bebas secara individual tidak berpengaruh signifikan terhadap variabel terikat.

\section{Koefisien Determinasi $\left(\mathbf{r}^{2}\right)$}

Tingkat goodness of fit dari garis regresi yang sesuai dengan data akan digunakan untuk mengetahui seberapa baik sebuah garis regresi sampel sesuai dengan datanya. Nilai dari r-square akan selalu berada di antara 0 dan 1. Semakin mendekati 1, semakin besar kemampuan variabel bebas untuk menjelaskan perilaku variabel terikat. Nilai r-square memberikan informasi mengenai proporsi variasi dari variabel terikat yang dijelaskan oleh variabel-variabel bebas sehingga memberikan ukuran sependapatan operasionala menyeluruh mengenai variasi dari variabel yang mempengaruhi variasi dari variabel lainnya.

\section{Uji SFA}

Setelah persamaan regresi sudah ditetapkan maka selanjutnya akan dilakukan pengukuran efisiensi pada DJP 
ISSN : $2406-7415$

E-ISSN : $2655-9919$

JURNAL AKUNTANSI DAN BISNIS KRISNADWIPAYANA

dengan menggunakan metode SFA yang menggunakan program Frontier 4.1. Hasil nilai efisiensi yang muncul berbentuk skor dari rentang 0-1. Artinya semakin mendekati satu maka akan semakin efisien DJP tersebut, begitu juga sebaliknya jika nilai SFA mendekati 0 maka akan semakin tidak efisien DJP tersebut.

\section{HASIL PENELITIAN PEMBAHASAN}

DAN

\section{Hasil Regresi}

Metode estimasi regresi penelitian ini mengunakan OLS yang diolah dengan EViews 4.1. Untuk hasil estimasi model OLS dengan variabel terikat penerimaan dana pajak (lihat Lampiran 1) menghasilkan nilai r-square sebesar 0,984376 atau 98,43 persen. Artinya persentase pengaruh beban operasional dan total aset terhadap penerimaan dana pajak sebagai variabel terikat sebesar 98,43 persen, atau variasi variabel bebas yang digunakan dalam model mampu menjelaskan sebesar 98,43 persen variabel terikat, sedangkan sisanya hanya sebesar 1,57 persen dipengaruhi dari variabel lain di luar model estimasi.

Model estimasi tersebut akan digunakan untuk pengolahan selanjutnya pada Frontier 4.1 untuk mencari nilai efisiensi yang dihasilkan DJP. Nilai efisiensi juga diperkirakan dengan estimasi maximum-likelihood untuk technical effect dari model OLS yang dipakai. Hasil estimasi stochastic frontier model dengan OLS dan MLE sedikit mengalami perbedaan. Terdapat variabel yang memiliki pengaruh signifikan pada estimasi OLS, namun berpengaruh tidak signifikan pada model estimasi MLE. Secara lengkap hasil estimasi OLS dan MLE digambarkan pada Tabel 2, berikut:
Tabel 2. Hasil regresi

\begin{tabular}{|c|c|c|c|}
\hline \multirow[t]{2}{*}{1} & \multirow{2}{*}{ Variabel } & \multicolumn{2}{|c|}{ Model } \\
\hline & & OLS & MLE \\
\hline \multirow{3}{*}{1} & $\begin{array}{l}\text { Penerimaan dana } \\
\text { pajak } \\
\text { (ln_penerimaan_pa } \\
\text { jak) }\end{array}$ & & \\
\hline & Konstanta & $\begin{array}{c}- \\
0.7960 \\
59\end{array}$ & $\begin{array}{c}0.41193 * \\
* *\end{array}$ \\
\hline & Prob & $\begin{array}{c}0.8085 \\
)\end{array}$ & $(0.7949)$ \\
\hline \multirow[t]{2}{*}{2} & $\begin{array}{l}\text { Beban oprasional } \\
\text { (ln_beban_oprasio } \\
\text { nal) }\end{array}$ & $\begin{array}{l}1.0976 \\
47 * * *\end{array}$ & $\begin{array}{c}0.25473 \\
* * *\end{array}$ \\
\hline & Prob & $\begin{array}{c}(0.0000 \\
)\end{array}$ & $(0.2311)$ \\
\hline \multirow{2}{*}{3} & $\begin{array}{l}\text { Total Aset } \\
\text { (ln_total_aset) }\end{array}$ & $\begin{array}{c}0.1066 \\
91 *\end{array}$ & $\begin{array}{c}0.11025 * \\
* *\end{array}$ \\
\hline & Prob & $\begin{array}{c}(0.0779 \\
)\end{array}$ & $(0.1102)$ \\
\hline \multirow{2}{*}{$\begin{array}{l}5 \\
6\end{array}$} & $\mathrm{R}^{2}$ & $\begin{array}{c}0.9843 \\
76\end{array}$ & - \\
\hline & Adj $R^{2}$ & $\begin{array}{c}0.9801 \\
04\end{array}$ & - \\
\hline \multirow[t]{2}{*}{7} & $\mathrm{~F}$ & $\begin{array}{c}230.419 \\
9 * * *\end{array}$ & - \\
\hline & Prob & $\begin{array}{c}0.0000 \\
)\end{array}$ & - \\
\hline \multirow[t]{2}{*}{$\begin{array}{l}8 \\
9\end{array}$} & Durbin /Watson & $\begin{array}{c}1.6434 \\
92\end{array}$ & - \\
\hline & Sigma-squared & - & 0.69203 \\
\hline \multirow[t]{2}{*}{10} & Gamma & - & 0.92233 \\
\hline & $\begin{array}{l}\text { Std. Error of } \\
\text { Gamma }\end{array}$ & - & 0.07493 \\
\hline \multirow{2}{*}{$\begin{array}{l}11 \\
12\end{array}$} & $\begin{array}{l}\text { Log likelihood } \\
\text { function }\end{array}$ & - & -2.15208 \\
\hline & Mean efficiency & - & 0.86732 \\
\hline
\end{tabular}

$$
\begin{array}{lll}
\text { Ket: } & * & \text { Signifikan pada } 10 \text { persen } \\
& * * & \text { Signifikan pada } 5 \text { persen } \\
& * * * & \text { Signifikan pada } 1 \text { persen }
\end{array}
$$

\section{Permodelan Penerimaan Dana Pajak}

Berdasarkan hasil yang ditunjukkan pada Tabel 2 bahwa hubungan antara beban operasional dan total aset terhadap penerimaan dana pajak pada DJP, 2012- 
2019 dapat dianalisis dengan persamaan berikut:

\section{ln_penerimaan_pajak ${ }_{\text {it }}=\mathbf{0 . 4 1 1 9 3}+$ \\ 0.25473 In_beban_operasional ${ }_{\text {it }}+$ 0.11025 ln_total_aset ${ }_{i t}+U_{t}-V_{t}$

Berdasarkan hasil estimasi nilai maximum likelihood pendekatan SFA yang diolah dengan menggunakan Frontier 4.1, maka didapatkan model dengan nilai gamma sebesar 0,92233 dengan standar erorr 0,07493. Artinya nilai koefisien gamma yang mendekati satu mengindikasikan bahwa variasi eror lebih banyak dipengaruhi oleh faktor random lainnya. Hasil dari koefisien gamma ini menunjukkan bahwa faktor random selain variabel independen dan inefisiensi teknis lebih mendominasi variasi eror. Untuk menentukan tingkat signifikansinya variabel yang digunakan dengan membandingkan t-ratio dibandingkan dengan t-tabel dengan uji two tailed, dengan hasil sebagai berikut:

Variabel beban operasional berpengaruh positif dan signifikan terhadap penerimaan dana pajak. Hasil statistik two tailed variabel beban operasional nilainya lebih kecil dari $d f 162$ pada level signifikansi satu persen yang menunjukkan nilai 2,6065. Sehingga, dapat diambil kesimpulan beban operasional berpengaruh signifikan terhadap penerimaan dana pajak. Untuk arah hubungan antara variabel beban operasional dengan penerimaan dana pajak dapat dilihat dari nilai koefisiennya yang bernilai 0,25473 , dari angka tersebut dapat diinterpretasikan bahwa hubungan antara beban operasional dengan penerimaan dana pajak adalah hubungan yang searah (positif). Karena apabila beban operasional meningkat sebesar satu persen maka nilai penerimaan dana pajak akan meningkat 0,255 persen, ceteris paribus.
Variabel total aset berpengaruh positif dan signifikan terhadap penerimaan dana pajak Hasil statistik two tailed variabel total aset nilainya lebih kecil dari $d f 162$ pada level signifikansi satu persen yang menunjukkan nilai 2,6065. Sehingga, dapat diambil kesimpulan total aset berpengaruh signifikan terhadap penerimaan dana pajak. Untuk arah hubungan antara variabel total aset dengan penerimaan dana pajak dapat dilihat dari nilai koefisiennya yang bernilai 0,11025 , dari angka tersebut dapat diinterpretasikan bahwa hubungan antara total aset dengan penerimaan dana pajak adalah hubungan yang searah (positif). Karena apabila total aset meningkat sebesar satu persen maka nilai penerimaan dana pajak akan meningkat sebesar 0,80 persen ceteris paribus.

\section{Pengukuran Technical Efficiency Penerimaan Dana Pajak}

Setelah dilakukannya estimasi, Tabel 3 dan Gambar 1 menunjukkan secara lengkap hasil pengukuran skor technical efficiency untuk penerimaan dana pajak, 2012-2019. Pengukuran efisiensi dengan metode parametrik ini akan menghasilkan skor technical efficiency dengan skala 0-1. Hasil yang memiliki skor satu maka menunjukkan semakin efisien DJP dalam penerimaan dana pajak, vise versa.

Tabel 3. Skor technical efficiency DJP menurut wilayah, 2012-2019 (persen)

\begin{tabular}{|c|c|c|c|c|c|c|c|c|c|}
\hline K & Nam & $\mathbf{2}$ & $\mathbf{2}$ & $\mathbf{2}$ & $\mathbf{2}$ & $\mathbf{2}$ & $\mathbf{2}$ & $\mathbf{2}$ & $\mathbf{2}$ \\
$\mathbf{0}$ & $\mathbf{a}$ & $\mathbf{0}$ & $\mathbf{0}$ & $\mathbf{0}$ & $\mathbf{0}$ & $\mathbf{0}$ & $\mathbf{0}$ & $\mathbf{0}$ & $\mathbf{0}$ \\
$\mathbf{d}$ & Kan & $\mathbf{1}$ & $\mathbf{1}$ & $\mathbf{1}$ & $\mathbf{1}$ & $\mathbf{1}$ & $\mathbf{1}$ & $\mathbf{1}$ & $\mathbf{1}$ \\
$\mathbf{e}$ & wil & $\mathbf{2}$ & $\mathbf{3}$ & $\mathbf{4}$ & $\mathbf{5}$ & $\mathbf{6}$ & $\mathbf{7}$ & $\mathbf{8}$ & $\mathbf{9}$ \\
\hline & \multirow{3}{*}{1} & 8 & 8 & 8 & 8 & 8 & 8 & 8 & 8 \\
& \multirow{2}{*}{ Kan } & 7. & 5. & 7. & 5. & 5. & 5. & 4. & 4. \\
& wil 1 & 2 & 4 & 2 & 4 & 5 & 2 & 8 & 5 \\
& & 3 & 7 & 7 & 6 & 6 & 0 & 6 & 3 \\
\hline 2 & Kan & 8 & 8 & 8 & 8 & 8 & 8 & 8 & 8 \\
\hline
\end{tabular}

Copyright (c) 2021 Ratna Herawati 
ISSN : $2406-7415$

E-ISSN : $2655-9919$

JURNAL AKUNTANSI DAN BISNIS KRISNADWIPAYANA

DOI: http://dx.doi.org/10.35137/jabk.v8i1.469

\begin{tabular}{|c|c|c|c|c|c|c|c|c|c|}
\hline & wil 2 & 5. & 7. & 7. & 7. & 7. & 7. & 7. & 8. \\
\hline & & 6 & 0 & 1 & 1 & 0 & 6 & 9 & 2 \\
\hline & & 4 & 9 & 1 & 4 & 8 & 9 & 8 & 8 \\
\hline & & 8 & 8 & 8 & 8 & 8 & 8 & 8 & 8 \\
\hline 3 & Kan & 7. & 7. & 5. & 5. & 5. & 4. & 4. & 3. \\
\hline 3 & wil 3 & 3 & 3 & 4 & 5 & 5 & 6 & 1 & 5 \\
\hline & & 2 & 2 & 6 & 3 & 5 & 3 & 0 & 7 \\
\hline & & 8 & 8 & 8 & 8 & 8 & 8 & 8 & 8 \\
\hline & Kan & 7. & 7. & 7. & 7. & 7. & 7. & 7. & 7. \\
\hline 4 & wil 4 & 1 & 1 & 1 & 1 & 2 & 2 & 2 & 2 \\
\hline & & 9 & 6 & 5 & 8 & 1 & 0 & 1 & 2 \\
\hline & & 8 & 8 & 8 & 8 & 8 & 8 & 8 & 8 \\
\hline 5 & Kan & 5. & 5. & 5. & 5. & 5. & 5. & 5. & 5. \\
\hline J & wil 5 & 6 & 6 & 5 & 6 & 6 & 6 & 6 & 6 \\
\hline & & 3 & 3 & 8 & 1 & 3 & 2 & 2 & 2 \\
\hline & & 8 & 8 & 8 & 8 & 8 & 8 & 8 & 8 \\
\hline & Kan & 7. & 7. & 7. & 7. & 7. & 7. & 7. & 7. \\
\hline 6 & wil 6 & 1 & 1 & 1 & 1 & 1 & 2 & 2 & 2 \\
\hline & & 0 & 2 & 6 & 6 & 8 & 0 & 2 & 4 \\
\hline & & 8 & 8 & 8 & 8 & 8 & 8 & 8 & 8 \\
\hline 7 & Kan & 5. & 5. & 5. & 5. & 5. & 5. & 5. & 5. \\
\hline & wil 7 & 5 & 4 & 5 & 4 & 6 & 5 & 5 & 5 \\
\hline & & 5 & 7 & 6 & 7 & 1 & 7 & 8 & 9 \\
\hline & & 8 & 8 & 8 & 8 & 8 & 8 & 8 & 8 \\
\hline 8 & Kan & 8. & 8. & 8. & 8. & 8. & 8. & 8. & 8. \\
\hline$\gamma$ & wil 8 & 5 & 5 & 5 & 5 & 5 & 5 & 5 & 5 \\
\hline & & 3 & 4 & 4 & 5 & 7 & 7 & 8 & 9 \\
\hline & & 8 & 8 & 8 & 8 & 8 & 8 & 8 & 8 \\
\hline & Kan & 7. & 7. & 7. & 7. & 7. & 7. & 7. & 7. \\
\hline 9 & wil 9 & 1 & 0 & 1 & 1 & 0 & 1 & 1 & 0 \\
\hline & & 2 & 8 & 0 & 5 & 8 & 0 & 0 & 9 \\
\hline & & 8 & 8 & 8 & 8 & 8 & 8 & 8 & 8 \\
\hline 1 & $\begin{array}{l}\text { Kan } \\
\text { wil }\end{array}$ & 8. & 8. & 8. & 8. & 8. & 8. & 8. & 8. \\
\hline 0 & $\begin{array}{l}\text { W1l } \\
10\end{array}$ & 5 & 5 & 5 & 5 & 5 & 5 & 5 & 5 \\
\hline & & 0 & 3 & 4 & 4 & 2 & 4 & 5 & 5 \\
\hline & & 8 & 8 & 8 & 8 & 8 & 8 & 8 & 8 \\
\hline 1 & wil & 7. & 7. & 7. & 7. & 7. & 7. & 7. & 7. \\
\hline 1 & & 1 & 1 & 1 & 1 & 1 & 2 & 2 & 2 \\
\hline & & 4 & 1 & 3 & 6 & 9 & 0 & 1 & 3 \\
\hline & & 8 & 8 & 8 & 8 & 8 & 8 & 8 & 8 \\
\hline 1 & $\begin{array}{l}\text { Nall } \\
\text { wil }\end{array}$ & 7. & 7. & 7. & 7. & 8. & 8. & 8. & 8. \\
\hline 2 & $\begin{array}{l}\text { W11 } \\
12\end{array}$ & 2 & 2 & 2 & 2 & 4 & 2 & 4 & 7 \\
\hline & & 2 & 0 & 0 & 2 & 7 & 2 & 7 & 2 \\
\hline 1 & Kan & 8 & 8 & 8 & 8 & 8 & 9 & 9 & 9 \\
\hline 3 & wil & 8. & 8. & 9. & 9. & 9. & 0. & 0. & 1. \\
\hline
\end{tabular}

Volume 8 Nomor 1 (Januari - April) 2021

\begin{tabular}{|c|c|c|c|c|c|c|c|c|c|}
\hline & 13 & 3 & 3 & 6 & 6 & 7 & 3 & 7 & 1 \\
\hline & & 4 & 7 & 6 & 8 & 1 & 7 & 7 & 8 \\
\hline & & 8 & 8 & 8 & 8 & 8 & 8 & 8 & 8 \\
\hline 1 & nan & 7. & 7. & 5. & 7. & 7. & 6. & 6. & 6. \\
\hline 4 & & 1 & 1 & 6 & 1 & 1 & 7 & 7 & 7 \\
\hline & & 3 & 9 & 1 & 0 & 2 & 9 & 8 & 7 \\
\hline & & 8 & 8 & 8 & 8 & 8 & 8 & 8 & 8 \\
\hline 1 & Kan & 7. & 7. & 7. & 7. & 5. & 5. & 5. & 5. \\
\hline 5 & W11 & 2 & 1 & 1 & 1 & 4 & 8 & 4 & 1 \\
\hline & & 0 & 4 & 6 & 9 & 6 & 0 & 6 & 2 \\
\hline & & 8 & 8 & 8 & 8 & 8 & 8 & 8 & 8 \\
\hline 1 & Kan & 7. & 7. & 7. & 7. & 5. & 5. & 5. & 5. \\
\hline 6 & & 2 & 1 & 1 & 1 & 4 & 7 & 4 & 0 \\
\hline & & 0 & 4 & 6 & 0 & 7 & 7 & 2 & 7 \\
\hline & & 8 & 8 & 8 & 8 & 8 & 8 & 8 & 8 \\
\hline 1 & wil & 7. & 7. & 7. & 7. & 5. & 5. & 5. & 5. \\
\hline 7 & & 0 & 1 & 1 & 1 & 4 & 7 & 4 & 1 \\
\hline & & 8 & 1 & 0 & 2 & 1 & 6 & 3 & 0 \\
\hline & & 8 & 8 & 8 & 8 & 8 & 8 & 8 & 8 \\
\hline 1 & Nail & 7. & 5. & 5. & 5. & 7. & 6. & 6. & 6. \\
\hline 8 & W11 & 0 & 6 & 5 & 6 & 0 & 1 & 1 & 1 \\
\hline & & 7 & 2 & 9 & 1 & 7 & 9 & 9 & 9 \\
\hline & & 8 & 8 & 8 & 8 & 8 & 8 & 8 & 8 \\
\hline 1 & Nall & 7. & 5. & 5. & 7. & 5. & 5. & 5. & 5. \\
\hline 9 & 10 & 2 & 7 & 8 & 2 & 4 & 6 & 4 & 2 \\
\hline & & 4 & 7 & 0 & 2 & 8 & 8 & 7 & 7 \\
\hline & & 8 & 8 & 8 & 8 & 8 & 8 & 8 & 8 \\
\hline 2 & Aall & 5. & 7. & 7. & 7. & 5. & 6. & 6. & 6. \\
\hline 0 & 20 & 4 & 0 & 1 & 1 & 4 & 4 & 4 & 4 \\
\hline & & 7 & 7 & 0 & 2 & 8 & 6 & 7 & 7 \\
\hline & & 8 & 8 & 8 & 8 & 8 & 8 & 8 & 8 \\
\hline 2 & wil & 5. & 7. & 7. & 7. & 5. & 6. & 6. & 6. \\
\hline 1 & 21 & 6 & 0 & 0 & 1 & 5 & 4 & 4 & 4 \\
\hline & & 3 & 7 & 7 & 0 & 8 & 7 & 6 & 6 \\
\hline & & 8 & 8 & 8 & 8 & 8 & 8 & 8 & 8 \\
\hline 2 & wil & 7. & 5. & 5. & 5. & 7. & 6. & 6. & 6. \\
\hline 2 & 22 & 0 & 6 & 4 & 6 & 0 & 1 & 1 & 1 \\
\hline & & 9 & 2 & 7 & 2 & 7 & 6 & 6 & 6 \\
\hline & & 8 & 8 & 8 & 8 & 8 & 8 & 8 & 8 \\
\hline 2 & wil & 7. & 7. & 7. & 5. & 5. & 5. & 4. & 4. \\
\hline 3 & $\begin{array}{l}\text { WII } \\
23\end{array}$ & 2 & 2 & 2 & 5 & 5 & 0 & 5 & 0 \\
\hline & & 6 & 6 & 6 & 3 & 7 & 4 & 3 & 2 \\
\hline & Kan & 8 & 8 & 8 & 8 & 8 & 8 & 8 & 8 \\
\hline 2 & wil & 7. & 7. & 7. & 7. & 7. & 7. & 7. & 7. \\
\hline & 24 & 0 & 1 & 1 & 1 & 1 & 2 & 2 & 2 \\
\hline
\end{tabular}


ISSN : $2406-7415$

E-ISSN : $2655-9919$

JURNAL AKUNTANSI DAN BISNIS KRISNADWIPAYANA DOI: http://dx.doi.org/10.35137/jabk.v8i1.469

Volume 8 Nomor 1 (Januari - April) 2021

\begin{tabular}{|c|c|c|c|c|c|c|c|c|c|}
\hline & & 7 & 1 & 0 & 6 & 8 & 0 & 3 & 5 \\
\hline \multirow{4}{*}{$\begin{array}{l}2 \\
5\end{array}$} & \multirow{4}{*}{$\begin{array}{l}\text { Kan } \\
\text { wil } \\
25\end{array}$} & 8 & 8 & 8 & 8 & 8 & 8 & 8 & 8 \\
\hline & & 7. & 7. & 7. & 7. & 7. & 7. & 7. & 7. \\
\hline & & 1 & 1 & 1 & 2 & 2 & 2 & 2 & 2 \\
\hline & & 7 & 7 & 7 & 2 & 1 & 3 & 4 & 6 \\
\hline \multirow{4}{*}{$\begin{array}{l}2 \\
6\end{array}$} & \multirow{4}{*}{$\begin{array}{l}\text { Kan } \\
\text { wil } \\
26\end{array}$} & 8 & 8 & 8 & 8 & 8 & 8 & 8 & 8 \\
\hline & & 7. & 7. & 7. & 7. & 5. & 5. & 5. & 5. \\
\hline & & 0 & 0 & 0 & 1 & 3 & 7 & 3 & 0 \\
\hline & & 8 & 8 & 9 & 1 & 6 & 2 & 8 & 4 \\
\hline \multirow{4}{*}{$\begin{array}{l}2 \\
7\end{array}$} & \multirow{4}{*}{$\begin{array}{l}\text { Kan } \\
\text { wil } \\
27\end{array}$} & 8 & 8 & 8 & 8 & 8 & 8 & 8 & 8 \\
\hline & & 5. & 5. & 5. & 5. & 5. & 5. & 5. & 5. \\
\hline & & 6 & 6 & 5 & 5 & 4 & 4 & 4 & 4 \\
\hline & & 0 & 1 & 7 & 8 & 7 & 8 & 5 & 3 \\
\hline \multirow{4}{*}{$\begin{array}{l}2 \\
8\end{array}$} & \multirow{4}{*}{$\begin{array}{l}\text { Kan } \\
\text { wil } \\
28\end{array}$} & 8 & 8 & 8 & 8 & 8 & 8 & 8 & 8 \\
\hline & & 7. & 5. & 5. & 5. & 5. & 4. & 4. & 4. \\
\hline & & 3 & 5 & 5 & 5 & 5 & 8 & 5 & 1 \\
\hline & & 6 & 6 & 5 & 7 & 8 & 5 & 0 & 4 \\
\hline \multirow{4}{*}{$\begin{array}{l}2 \\
9\end{array}$} & \multirow{4}{*}{$\begin{array}{l}\text { Kan } \\
\text { wil } \\
29\end{array}$} & 8 & 8 & 8 & 8 & 8 & 8 & 8 & 8 \\
\hline & & 5. & 5. & 5. & 5. & 5. & 5. & 5. & 5. \\
\hline & & 5 & 5 & 5 & 4 & 5 & 5 & 5 & 4 \\
\hline & & 4 & 5 & 1 & 7 & 5 & 0 & 0 & 9 \\
\hline \multirow{4}{*}{$\begin{array}{l}3 \\
0\end{array}$} & \multirow{4}{*}{$\begin{array}{l}\text { Kan } \\
\text { wil } \\
30\end{array}$} & 8 & 8 & 8 & 8 & 8 & 8 & 8 & 8 \\
\hline & & 7. & 7. & 7. & 7. & 7. & 7. & 7. & 7. \\
\hline & & 1 & 1 & 0 & 0 & 1 & 0 & 0 & 0 \\
\hline & & 2 & 3 & 9 & 7 & 2 & 9 & 8 & 8 \\
\hline \multirow{4}{*}{$\begin{array}{l}3 \\
1\end{array}$} & \multirow{4}{*}{$\begin{array}{l}\text { Kan } \\
\text { wil } \\
31\end{array}$} & 8 & 8 & 8 & 9 & 8 & 9 & 9 & 9 \\
\hline & & 8. & 9. & 9. & 0. & 9. & 0. & 1. & 1. \\
\hline & & 5 & 6 & 8 & 8 & 6 & 7 & 0 & 4 \\
\hline & & 6 & 6 & 3 & 1 & 9 & 3 & 7 & 1 \\
\hline \multirow{4}{*}{$\begin{array}{l}3 \\
2\end{array}$} & \multirow{4}{*}{$\begin{array}{l}\text { Kan } \\
\text { wil } \\
32\end{array}$} & 8 & 8 & 8 & 8 & 8 & 8 & 8 & 8 \\
\hline & & 6. & 6. & 6. & 7. & 7. & 7. & 7. & 7. \\
\hline & & 4 & 4 & 4 & 1 & 1 & 3 & 6 & 8 \\
\hline & & 0 & 0 & 0 & 4 & 7 & 9 & 2 & 5 \\
\hline \multirow{4}{*}{$\begin{array}{l}3 \\
3\end{array}$} & \multirow{4}{*}{$\begin{array}{l}\text { Kan } \\
\text { wil } \\
33\end{array}$} & 8 & 8 & 8 & 8 & 8 & 8 & 8 & 8 \\
\hline & & 6. & 6. & 6. & 5. & 5. & 5. & 5. & 4. \\
\hline & & 4 & 4 & 4 & 6 & 4 & 2 & 0 & 7 \\
\hline & & 0 & 0 & 0 & 2 & 9 & 9 & 3 & 7 \\
\hline \multirow{4}{*}{$\begin{array}{l}3 \\
4\end{array}$} & Insta & 8 & 8 & 8 & 8 & 8 & 8 & 8 & 8 \\
\hline & nsi & 5. & 3. & 3. & 3. & 3. & 2. & 1. & 1. \\
\hline & Pusa & 1 & 0 & 0 & 0 & 0 & 2 & 7 & 3 \\
\hline & $\mathrm{t}$ & 3 & 5 & 5 & 8 & 2 & 1 & 9 & 7 \\
\hline
\end{tabular}

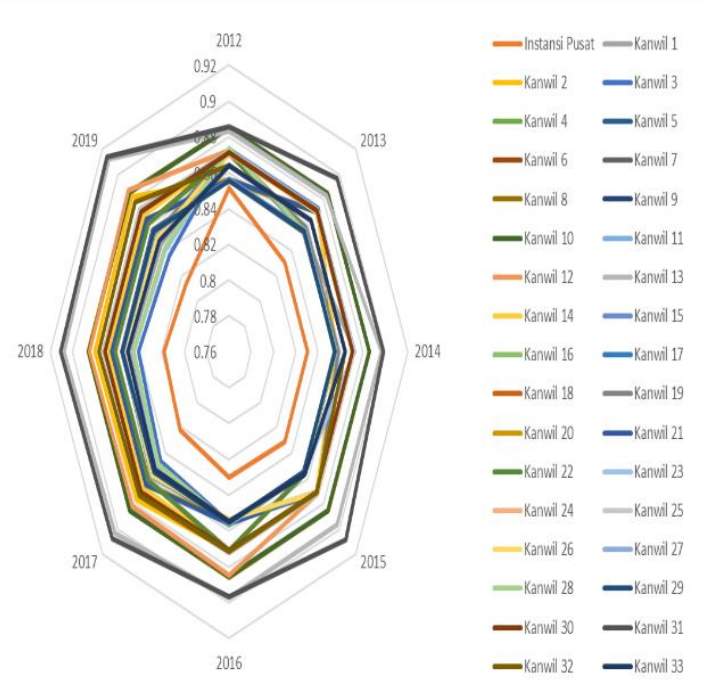

Gambar 1. Perkembangan technical efficiency DJP menurut wilayah, 20122016 (persen)

Dari hasil perhitungan skor technical efficiency penerimaan dana pajak DJP menunjukkan bahwa selama rentang periode penelitian, 2012-2019 tidak terdapat nilai efisiensi yang sempurna dengan skor satu. Ketimpangan yang tidak terlalu besar atas efisiensi DJP, 2012-2019 dalam penerimaan dana pajak (lihat Gambar 1). Hal ini dapat dilihat dari ratarata keseluruhan rentang skor technical efficiency maksimum sebesar 90,22 persen di Kanwil DJP Wajib Pajak Besar dan minimum sebesar 82,83 persen di Instansi Pusat. Jika dilihat secara keseluruhan technical efficiency DJP dalam penerimaan dana pajak sebesar 86,63 persen, yang berarti masih terdapat 13,36 persen technical inefficiency dalam pengelolaan DJP yang dapat dioptimalkan untuk mencapai nilai efisiensi yang sempurna. 
ISSN : $2406-7415$

E-ISSN : $2655-9919$

JURNAL AKUNTANSI DAN BISNIS KRISNADWIPAYANA

DOI: http://dx.doi.org/10.35137/jabk.v8i1.469

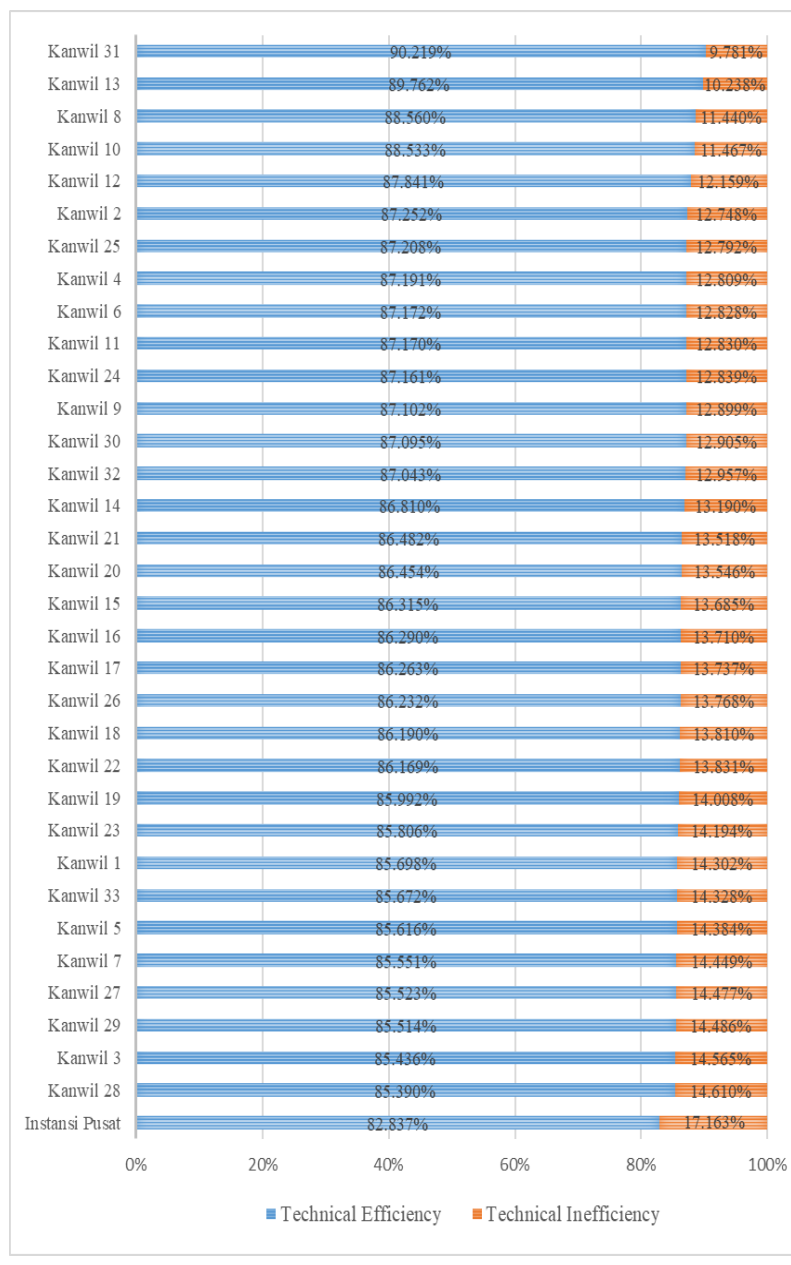

Gambar 2. Skor rata-rata technical efficiency dan technical inefficiency

DJP menurut wilayah, 2012-2019

Setelah memperoleh hasil skor technical efficiency, maka kita akan mengetahui statistik deskriptif atas hasil perhitungan technical efficiency (lihat Tabel 4) yang terdiri atas nilai minimum, nilai maksimum, rata-rata dan standar deviasi DJP dalam penerimaan dana pajak yang digunakan.

\section{Tabel 4. Statistik deskriptif nilai} efisiensi SFA

$\begin{array}{cccc}\text { Min } & \text { Max } & \text { Mean } & \begin{array}{c}\text { Std. } \\ \text { Deviatio } \\ \text { n }\end{array} \\ 81,37 & 90,21 & 86,63 & 1.3472\end{array}$

Volume 8 Nomor 1 (Januari - April) 2021

$$
\text { si } \quad 0 \% \quad 9 \% \quad 4 \% \quad \%
$$

Nilai rata-rata technical efficiency sebesar, artinya technical efficiency DJP, 2012-2019 mencapai 86,634 persen. Dengan kata lain, masih ada 13,366 persen peluang yang bisa dioptimalkan untuk mencapai tingkat operasional yang paling efisien. Periode yang paling efisien bagi DJP dalam pengelolaan penerimaan dana pajak ditunjukkan pada 2012 di Kanwil DJP Wajib Pajak Besar dengan nilai technical efficiency sebesar 90,219 persen. Sedangkan periode yang paling tidak efisien ditunjukkan pada 2019 di Instansi Pusat dengan nilai technical efficiency sebesar 81,370 persen. Untuk distribusi nilai technical efficiency digambarkan pada Tabel 5 berikut:

\section{Tabel 5. Distribusi nilai technical efficiency}

\begin{tabular}{|c|c|c|c|}
\hline Nilai & Frekuens & Persentas & Kategor \\
\hline $\begin{array}{c}\text { Efisiens } \\
\mathbf{i}\end{array}$ & $\mathbf{i}$ & e & $\mathbf{i}$ \\
\hline $\begin{array}{c}\text { NTE }< \\
85,62 \%\end{array}$ & 7 & 20,59 & $\begin{array}{l}\text { Tidak } \\
\text { efisien }\end{array}$ \\
\hline $85,62 \%$ & 10 & 29,41 & \\
\hline $\begin{array}{c}\leq \mathrm{NTE} \\
< \\
86,31 \%\end{array}$ & & & $\begin{array}{l}\text { Kurang } \\
\text { efisien }\end{array}$ \\
\hline $86,31 \%$ & 7 & 20,59 & \\
\hline $\begin{array}{c}\leq \mathrm{NTE} \\
<87,17 \\
\%\end{array}$ & & & $\begin{array}{l}\text { Cukup } \\
\text { efisien }\end{array}$ \\
\hline $\begin{array}{c}\text { NTE } \geq \\
87,17 \%\end{array}$ & 10 & 29,41 & Efisien \\
\hline TOTAL & 34 & 100 & \\
\hline
\end{tabular}

Pengelompokan nilai technical efficiency dilakukan dengan membaginya menjadi empat kategori dengan menggunakan persentil kuartile \pm standar deviasi, antara lain:

1. Nilai technical efficiency $<85,62$ persen adalah DJP dalam penerimaan dana pajak dengan kategori tidak efisien 
ISSN : $2406-7415$

E-ISSN : $2655-9919$

JURNAL AKUNTANSI DAN BISNIS KRISNADWIPAYANA

DOI: http://dx.doi.org/10.35137/jabk.v8i1.469

Volume 8 Nomor 1 (Januari - April) 2021

2. Nilai technical efficiency antara 85,62 persen - 86,31 persen adalah DJP dalam penerimaan dana pajak dengan kategori kurang efisien

3. Nilai technical efficiency antara 86,31 persen - 87,17 persen adalah DJP dalam penerimaan dana pajak dengan kategori cukup efisien

4. Nilai technical efficiency $\geq 87,17$ persen adalah DJP dalam penerimaan dana pajak dengan kategori efisien

Dengan klasifikasi tersebut, maka terdapat tujuh Kanwil DJP atau sebesar 20,59 persen (Instansi Pusat; Kanwil DJP Bali; Kanwil DJP Sumatera Utara II; Kanwil DJP Nusa Tenggara; Kanwil DJP Sulawesi Utara, Tengah dan Maluku Utara; Kanwil DJP Bengkulu dan Lampung; Kanwil DJP Sumatera Barat dan Jambi) yang beroprasi secara tidak efisien, 10 Kanwil DJP atau 29,41 persen (Kanwil DJP Jawa Barat III; Kanwil DJP Aceh; Kanwil DJP Kalimantan Barat; Kanwil DJP D.I. Yogyakarta; Kanwil DJP Jawa Timur III; Kanwil DJP Jawa Tengah II; Kanwil DJP Sulawesi Selatan, Barat dan Tenggara; Kanwil DJP Jawa Tengah I; Kanwil DJP Jawa Barat II; Kanwil DJP Jawa Barat I) yang beroprasi secara kurang efisien, tujuh Kanwil DJP atau 20,49 persen (Kanwil DJP Jawa Timur I; Kanwil DJP Jawa Timur II; Kanwil DJP Banten; Kanwil DJP Jakarta Selatan II; Kanwil DJP Papua dan Maluku; Kanwil DJP Jakarta Barat; Kanwil DJP Kalimantan Selatan dan Tengah) yang beroprasi cukup efisien dan terdapat 10 Kanwil DJP atau 29,41 persen (Kanwil DJP Jakarta Timur; Kanwil DJP Sumatera Selatan dan Babel; Kanwil DJP Riau dan Kepulauan Riau; Kanwil DJP Kalimantan Timur; Kanwil DJP Sumatera Utara I; Kanwil DJP Jakarta Utara; Kanwil DJP Jakarta Selatan; Kanwil DJP Jakarta Pusat; Kanwil DJP

Jakarta Khusus; Kanwil DJP Wajib Pajak Besar) yang beroprasi secara efisien.

\section{Pembahasan}

Perhitungan efisiensi yang ditunjukkan dari skor technical eficiency secara rata-rata maupun keseluruhan objek penelitian yang diamati ini sudah menunjukkan hasil yang relatif baik. Tentunya hal ini mendukung rencana strategis atau master plan dari DJP yang sebagaimana ditetapkan dalam Keputusan Direktur Jenderal Pajak Nomor KEP95/PJ/2015 merupakan dokumen perencanaan yang berisi visi, misi, nilai, tujuan, sasaran, strategi, program, dan indikator kinerja Direktorat Jenderal Pajak untuk periode lima tahun mendatang (lihat Gambar 3). Penyusunan rencana strategis ini memberikan petunjuk atas pelaksanaan program-program dari DJP yang diharapkan mampu untuk menghimpun penerimaan pajak yang efisien melalui tingkat kepatuhan wajib pajak yang tinggi.

Peta strategis merupakan gambaran atas hubungan kausalitas antara sasaran yang ingin dicapai dengan strategi pencapainnya. Sasaran strategis ini terdiri dari: sumber daya manusia yang kompetitif, organisasi dan transformasi yang handal, sistem informasi manajemen yang terintegrasi dan pelaksaan anggaran yang optimal. Dalam proses pelaksanaannya ini mendukung proses yang terdiri atas pelayanan prima, peningkatan efektivitas penyuluhan, peningkatan efektivitas kehumasan peningkatan ekstensifikasi perpajakan, peningkatan pengawasan wajib pajak, peningkatan efektivitas pemeriksaan, peningkatan efektivitas penegakan hukum, dan peningkatan kehandalan data. Selanjutnya proses tersebut ditunjang dengan pemenuhan layanan publik yang 
ISSN : $2406-7415$

E-ISSN : $2655-9919$

JURNAL AKUNTANSI DAN BISNIS KRISNADWIPAYANA

DOI: http://dx.doi.org/10.35137/jabk.v8i1.469

Volume 8 Nomor 1 (Januari - April) 2021

diharapkan menghasilkan tingkat kepatuhan wajib pajak yang tinggi sehingga dapat mengoptimalkan penerimaan pajak.

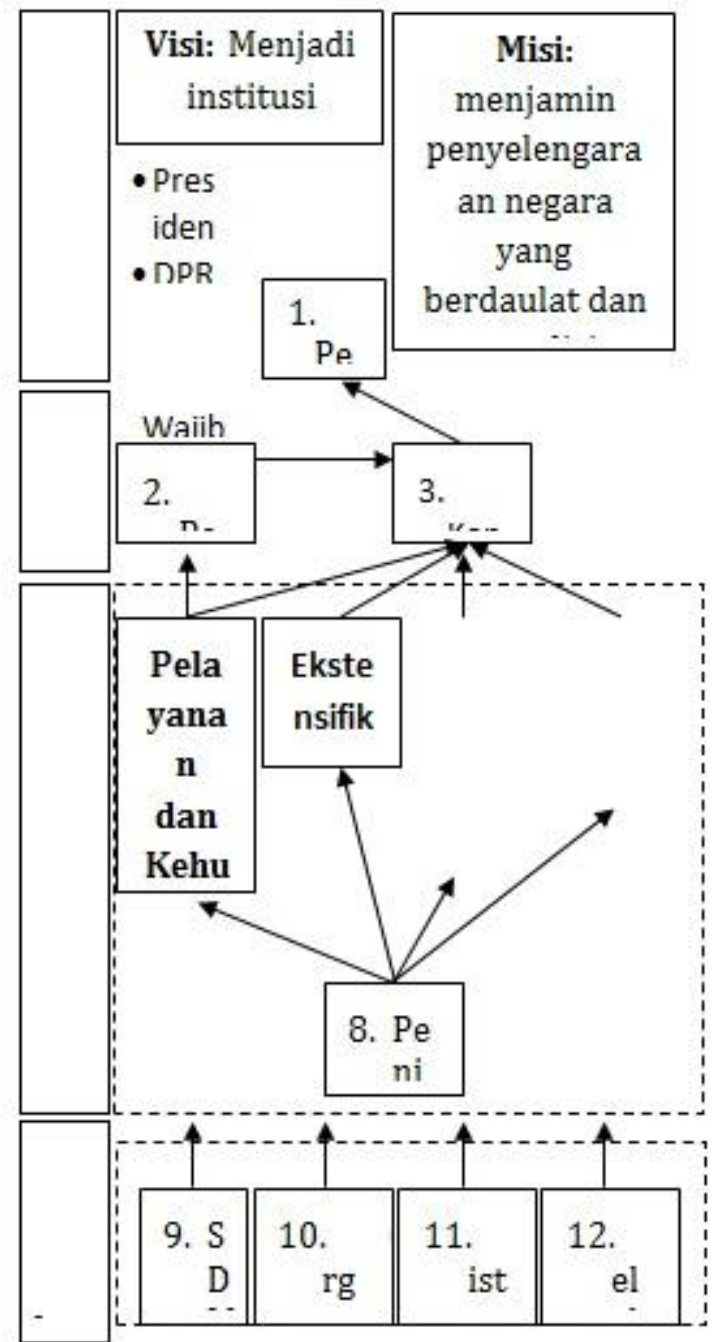

Sumber : Laporan keuangan DJP (2016) Gambar 3 : Peta Strategi DJP

\section{KESIMPULAN DAN SARAN}

Berdasarkan hasil analisis dan pembahasan yang telah diuraikan mengenai tingkat efisiensi pengelolaan dana pajak DJP pada 2012-2019, maka dapat ditarik beberapa kesimpulan sebagai berikut:

Hasil estimasi antara metode OLS dan MLE yang digunakan dalam penelitian ini menunjukkan perbedaan. Berdasarkan hasil dari OLS dan MLE beban operasional dan total aset terhadap penerimaan dana pajak baik secara parsial maupun keseluruhan sama-sama menunjukkan hubungan yang positif dan signifikan, hanya saja level signifikansinya berbeda.

Hasil efisiensi rata-rata penerimaan dana pajak DJP, 2012-2019 dengan menggunakan metode parametrik (SFA) sebesar 86,634 persen. Artinya masih terdapat 13,366 persen peluang yang dapat dioptimalkan untuk mencapai tingkat efisiensi operasional DJP secara penuh. DJP yang paling efisien dalam kegiatan operasionalnya yaitu Kanwil DJP Wajib Pajak Besar (Jakarta) dengan nilai technical efficiency sebesar 90,22 persen. Sedangkan Instansi Pusat (Jakarta) menjadi DJP yang paling tidak efisien beroprasi dengan nilai technical efficiency sebesar 82,84 persen.

Guna mengoptimalkan potensi yang dimiliki oleh DJP sehingga nilai efisiensi DJP dalam pengelolaan dana pajak dapat meningkat maka seluruh kantor DJP khususnya yang memiliki nilai technical efficiency dengan rentang yang tidak efisien harus lebih memperhatikan faktorfaktor yang mempengaruhi tingkat efisiensi penerimaan dana pajak, berdasarkan hasil diketahui bahwa nilai 
efisiensi penerimaan dana pajak dipengaruhi oleh beban operasional. Sehingga variabel beban operasional ini dapat menjadi fokus internal bagi DJP dalam lebih meningkatkan efisiensinya. Serta dapat menggunakan hasil pengukuran efisiensi tersebut sebagai salah satu pertimbangan dalam usulan pemberian reward (penghargaan) bagi unit kerja yang telah berkinerja dengan baik.

\section{DAFTAR PUSTAKA}

Ahmadi. (2006). Perlindungan Hukum Bagi Wajib Pajak Dalam Penyelesaian Sengketa Pajak. Cet.1. Bandung: PT. Refika Aditama.

Archer, Timothy Scott (2010). The Efficiency Theory: Improving Society by Eliminating Wasteful Programs, Restructuring the Economy, and Fixing Education. New York: CreateSpace Independent Publishing Platform http://www.theefficiencytheory.com/ The_Efficiency Theory.pdf

Barros, C. P. (2007). Technical and Allocative Efficiency of Tax Offices: A Case Study. International Journal of Public Sector Performance Management, 1(1), 41-61.

Bauer, Paul W., Allen N. Berger, Gary D Ferrier, and Humphrey, David B. (1998). "Consistency Conditions for Regulatory Analysis of Financial Institutions: A Comparison of Frontier Efficiency Methods", Financial Services Working Paper, 02/97, Federal Reserve.

Hjalmarsson, L., Kumbhakar, S. C., \& Heshmati, A. (1996). DEA, DFA and SFA: A Comparison. Journal of Productivity Analysis, 7(2-3), 303327.
Kader, Muhamad Kubrajaya, Harijanto Sabijono, \& Heince R.N. Wokas. (2015). "Pengaruh Penerapan Elektronik Surat Pemberitahuan (eSPT) terhadap Efisiensi Pengisian Surat Pemberitahuan (SPT) Wajib Pajak di Kecamatan Sario Kota Manado". Jurnal Berkala Ilmiah Efisiensi. 15(4), 63-73.

Mahsun, M. (2014). Pengukuran Kinerja Sektor Publik. Yogyakarta: BPFEYogyakarta.

Mardiasmo. (2009). Akuntansi Sektor Publik. Yogyakarta: Penerbit Andi Yogyakarta.

Moesen, W., and Persoon, A. (2002). "Measuring and Explaining the Productive Efficiency of Tax Offices: A Non-parametric Best Practice Frontier Approach". Tijdschrift Voor Economie En Management, 47(3), 399-416.

OECD. (2013). Government at a Glance 2013. OECD Publishing.

Permono, Iswardono S. dan Darmawan (2000) "Analisis Efisiensi Industri Perbankan di Indonesia (Studi kasus Bank-bank Devisa di Indonesia Tahun 1991 - 1996)". Journal of Indonesian Economy and Business, 15 (1)

Sadjiarto, A. (2000). Akuntabilitas dan Pengukuran Kinerja Pemerintahan. Jurnal Akuntansi dan Keuangan, 2(2), 138-150.

Setiyaji, G., \& Amir, H. (2005). Evaluasi Kinerja Sistem Perpajakan Indonesia. Jurnal Ekonomi Univ Indonusa Eka Unggul, 1, 1-13.

Thirtle, C., Shankar, B., Chitkara, P., Chatterjee, S., \& Mohanty, M. S. (2000). Size does matter: Technical and scale efficiency in Indian state tax jurisdictions. Review of Development Economics, 4(3), 340352. 
ISSN : $2406-7415$

E-ISSN : 2655 - 9919

JURNAL AKUNTANSI DAN BISNIS KRISNADWIPAYANA

DOI: http://dx.doi.org/10.35137/jabk.v8i1.469

Volume 8 Nomor 1 (Januari - April) 2021 